\title{
FDI and Global Economic Integration: A Welfare Analysis
}

\author{
Yu-Ter Wang ${ }^{1}$ \\ ${ }^{1}$ Department of Economics and Finance, Ming Chuan University, Taoyuan, Taiwan \\ Correspondence: Yu-Ter Wang, Professor, Department of Economics and Finance, Ming Chuan University, 5 De \\ Ming Rd., Gwei Shan, Taoyuan 333, Taiwan. Tel: 886-3-350-7001 ext. 3453.
}

Received: June 15, 2019

doi:10.20849/iref.v3i2.596

\author{
Accepted: August 1, 2019 \\ Online Published: December 15, 2019 \\ URL: https://doi.org/10.20849/iref.v3i2.596
}

\begin{abstract}
This paper investigates the welfare impact on all member countries when nonmember countries invest in a member of an economic region, in which capital is allowed to move freely. It is shown that the nonmember investment will affects the welfare of all members despite that some members do not receive such investment directly. In general, the results depend on the relative magnitude of the tariff revenue effect, the tax revenue effect and the capital returns effect. Specific conditions for welfare change in each member country as well as the criterion for a common external tariff which ensures welfare improvement in all the member countries are derived.
\end{abstract}

Keywords: global economic integration, FDI, common external tariff

\section{Introduction}

The world is entering the last decade of the century in the midst of profound and rapid change. Among the many developments that are occurring, the trend toward regional economic integration and globalization of investment strategies is of particular importance. The impacts of regional economic integration on the behavior of transnational corporations, in particular foreign direct investment (FDI) activities, have caught the attention of many policy makers and trade theorists. It is widely recognized that regional economic integration could produce the so-called investment creation effect. A recent example is that during the 1985-1990 period Japans direct investments in European Community have expanded nearly six-fold (Balasubramanyan and Greenaway [1992]). Some authors have argued that the incentive for Japan and other third countries to invest in the EC will be stronger the more successfully the EC integrates its internal market (Heitger and Stehn [1990]). In consequence, the issue of nonmember investment is certain to carry weight in the evolution of international capital mobility and economic integration theories.

The impact of FDI on national welfare has long been a subject of interest in the international trade literature. Papers such as MacDougall [1960], Brecher and Diaz Alejandro [1977], Brecher and Findlay [1983] and Srinivasan [1983] are well-known. However, none of them has investigated the issue in the context of an economic integration. On the contrary, while a number of authors have included FDI in their analysis related to economic integration (Scully and Yu [1974], Tironi [1982], Yu [1985], Parai and Yu [1989]), to our knowledge only Myagiwa and Young [1996], Wooton [1998], Webb [1998] and Michael [2002] have considered the impact of capital flows within an economic region. Myagiwa and Young [1996], in particular, have focused on the economic interdependencies arising from capital movements within the economic region when they study the welfare impact of a member country's commercial policy Interesting as they are, however, the problems dealt with by Miyagiwa and Young are more relevant to the investment diversion effect within the region. Since the main purpose of this paper is to study the welfare implication of the investment creation effect, we will instead focus on an exogenous increase in investment into the economic region by nonmember countries. (Note 1) It is hoped that the present study can serve as a complement of Myagiwa and Young [1996] on the one hand, and bridge the gap between theories of international capital movements and those of economic integration on the other.

The model used in our analysis closely follows that of Myagiwa and Young [1996]. To be precise, the economic region is assumed to be a "small union," i.e., the economic region imposes a common external tariff but it is too small to influence the terms of trade in the outside world. However, for historical, geographical or socio cultural reasons, free capital movements are allowed in the economic region, though international migration is still 
prohibited. Ricardo-Viner or specific factor technologies are assumed to capture the salient feature of FDI that it tends to concentrate in a few specific industries (Srinivasan [1983], Miyagiwa and Young [1996]).

The remainder of the paper is organized as follows. Section II sets out the model. Section III performs comparative static analysis to examine how investment from nonmember countries into the economic region affects the welfare of each member country Section IV provides a summary and discusses some possible extensions.

\section{The Model}

Consider two countries, $A$ and $B$, each producing goods 1 and 2. Good 1 is produced with land and labor, while good 2 is produced with capital and labor; land and capital are the specific factors for good 1 and good 2, respectively. The production functions of both goods exhibit constant returns to scale, with diminishing marginal productivity for each input.

Assume that countries $A$ and $B$ form an economic region where tariffs and other trade barriers are abolished and a common external tariff is imposed on imports from the outside world. For convenience, the outside world or the nonmember countries as a whole is sometimes referred to as country $C$ in the following discussion. While capital is perfectly mobile within the economic region, labor is not allowed to migrate internationally, it is mobile across sectors. Both member countries import good 2 from country $C$. Following the convention in the discussion of customs union theory, the economic region is assumed to face fixed world commodity prices. Furthermore, we assume that country $C$ invests in country $A$ only since the latter offers generally more favorable incentives and/or less unfavorable disincentives for nonmember FDI than those of country $B$. While all the existing incentive systems are extremely complex, financial or fiscal incentive policies such as tax holidays and tax concessions are undoubtedly the most popular ones among the host countries. To focus our attention on the welfare impact, we therefore simply assume that the more favorable position of country $A$ for nonmember FDI is captured by a lower tax rate on nonmember capital income than that of country $B$. (Note 2 )

Using good 1 as the numeraire, the notations used in the following analysis are:

$q=$ the world market price of good 2;

$t=$ the specific import tariff imposed on good $\mathrm{z}$ by the economic region;

$p=q+t$, the intra-regional price of good 2 ;

$u^{j}=$ country $j^{\prime}$ s utility level;

$k^{j}=$ the capital stocks utilized in country $j$;

$\bar{k}^{j}=$ country $j$ 's capital endowment;

$i^{*}=$ the capital stocks owned by country $C$ in country $A$;

$i=$ capital stocks owned by country $B$ in country $A$ (if $i<0$, then it is the

capital stocks owned by country $A$ in country $B$ );

$e^{j}=$ country $j$ 's expenditure function;

$r^{j}=$ country $j^{\prime}$ s revenue function;

$\tau=$ the tax rate levied by country $A$ on country $C$ 's capital income;

$\tau^{j}=$ the tax rate levied by country $j$ on its own and member country's

capital income;

$j=A, B$.

As capital is mobile within the economic region, the capital stocks utilized in country $A$ includes its own capital endowment, capital stocks owned by country $B$ in country $A$, and the capital stocks owned by country $C$. That is, $k^{A}=\bar{k}^{A}+i+i^{*}$. On the other hand, as country $B$ receives no investment from the nonmember countries, we have $k^{B}=\bar{k}^{B}-i$. Under such circumstances and assuming that both $\mathrm{A}$ and $\mathrm{B}$ are nonspecialized in production, the equilibrium can be characterized as

$$
\begin{gathered}
e^{A}\left(p, u^{A}\right)=r^{A}\left(p, k^{A}\right)-\left[(1-\tau) /\left(1-\tau^{A}\right)\right] i^{*}-\not i+t\left(e_{p}^{A}-r_{p}^{A}\right), \\
e^{B}\left(p, u^{B}\right)=r^{B}\left(p, k^{B}\right)+\gamma i+t\left(e_{p}^{B}-r_{p}^{B}\right), \\
r_{k}^{A}\left(1-\tau^{A}\right)=r_{k}^{B}\left(1-\tau^{B}\right)=\gamma,
\end{gathered}
$$


where $e_{p}^{j}=\partial e^{j} / \partial p$ and $r_{p}^{j}=\partial r^{j} / \partial p$ are country $j^{\prime}$ s demand for and output supply of good 2, respectively; $r_{k}^{j}=\partial r^{j} / \partial k^{j}$ is the returns to capital in country $j$. Equations (1) and (2) imply that, for balanced trade, the expenditure must be equal to the sum of the value of production, the net capital income, and the tariff revenue in each country. Note that country $A$ 's tax rate on the capital income of the member country $\left(\tau^{A}\right)$ could be greater than, equal to, or less than that on the capital income of country $C(\tau)$, depending on the relevant incentives and disincentives offered to nonmember FDI. However, $\tau$ is certainly lower than its counterpart in country $B$, implying nonmember FDI in country $A$ only Equation (3) states that perfect capital mobility within the economic region should equalize the net returns to capital owned by member countries in the economic region, which is denoted by $\gamma$. The three equations in (1) - (3) determine the three endogenous variables, $u^{A}, u^{B}$ and $i$.

\section{Effects of FDI From the Nonmember Countries}

Suppose that there is an exogenous increase in FDI from country C into country A. In the context of the economic region specified above, the welfare impact of the increase in FDI differs from that of the traditional investment-trade model, in which the impact is absorbed completely by the host country. In the present case, an increase in FDI from country $\mathrm{C}$ will definitely lead to an increase in the capital stocks utilized by both member countries, even though country $C$ only invests in country $A$. This can be shown by partially differentiating (3) with respect to $i^{*}$ :

$$
\partial k^{i} / \partial i^{*}=1-\left[v^{j} r_{k k}^{j} /\left(v^{A} r_{k k}^{A}+v^{B} r_{k k}^{B}\right)\right]>0, \quad j=A, B,
$$

where $v^{j}=1-\tau^{j}$ and $r_{k k}^{j}=\partial^{2} r^{j} / \partial k^{j 2}$. That capital is a specific factor in the protected sector together with the assumption of diminishing marginal productivity implies $r_{k k}^{j}<0$. This in turn gives us the positive sign of equation (4). Consequently, increasing FDI from country $C$ into country $A$ causes the capital stocks utilized in both member countries to rise. The relative magnitude of the increase in $k^{A}$ and $k^{B}$ depends on the slopes of the respective capital returns curves as well as the tax rates on capital income in the two member countries.

Now consider the welfare effects of the increase in FDI from country $C$, given the common external tariff and the tax rates on capital income. Differentiating equations (1) and (2), using equation (4) and rearranging terms give us

$$
\begin{gathered}
e_{u}^{A}\left(1-t c_{e}^{A}\right) \partial u^{A} / \partial i^{*}=\left[-\left(1-\tau^{A}\right) i r_{k k}^{A} \partial k^{A} / \partial i^{*}-(1-\tau) i^{*} r_{k k}^{A} \partial k^{A} / \partial i^{*}\right] \\
+\left\{\tau^{A}\left[r_{k}^{A}\left(\partial k^{A} / \partial i^{*}-1\right)\right]+\tau r_{k}^{A}\right\}-t r_{p k}^{A} \partial k^{A} / \partial i^{*} \\
e_{u}^{B}\left(1-c_{e}^{B}\right) \partial u^{B} / \partial i^{*}=\left[\left(1-\tau^{B}\right) i r_{k k}^{B}+\tau^{B} r_{k}^{B}-t r_{p k}^{B}\right] \partial k^{B} / \partial i^{*}
\end{gathered}
$$

where $c_{e}^{i}=e_{p u}^{j} / e_{u}^{i}$. Assuming that all goods are normal, then $e_{u}^{i}\left(1-t c_{e}^{i}\right)$ on the left-hand side of equations (5) and (6) is positive (Miyagiwa and Young [1996]). Therefore, the welfare impact on each member country depends on the sign of the right-hand side of equations (5) and (6).

Let us first look at the welfare consequence for country $B$. On the right hand side of equation (6), the first term $\left(l-\tau^{B}\right) i r_{k k}^{B}$ captures the impact of the increase in $i^{*}$ on the net capital payments between the member countries, the capital returns effect. The second term $\tau^{B} r_{k}^{B}$ represents the change in the tax revenue caused by the increase in nonmember FDI into the economic region, the tax revenue effect. Since the capital employed in country $B$ increases with the inflow of nonmember FDI into country $A$ (see equation (4)), the tax revenue effect must be positive. Finally, given the fact that $r_{p k}^{j}$ ispositive, (Note 3) the protected sector in both member countries will expand following the increase in $i^{*}$. At constant prices, the rise in the production of good 2 must lead to a decrease in imports and thus in tariff revenue, which is captured by the negative tariff revenue effect $-t r_{p k}^{B}$. As the tax revenue effect and the tariff revenue effect have opposite signs and the sign of the capital returns effect depends upon whether country $B$ is a capital importer or a capital exporter, there is generally no way to be sure of the welfare impact on country B. However, defining $\sigma^{j} \equiv-k^{j} r_{k k}^{j} / r_{k}^{j}, j=A, B$, as the elasticity of the marginal product curve of capital in country $j$, it can be shown that the sum of the capital returns effect and the 
tax revenue effect is nonpositive if $i>0$ and $\tau^{B} \leq \sigma^{B} i /\left(\sigma^{B} i+k^{B}\right)<1$. In other words, when country $B$ is a capital exporter and with a sufficiently low tax rate on capital income, its welfare will decrease with the nonmember capital inflow into country $A$. The economic intuition is that FDI from $C$ reduces the returns to capital in the economic region, as a capital exporter country $B$ suffers from the capital returns effect in excess of the tax revenue effect if $\tau^{B}<\sigma^{B} i /\left(\sigma^{B} i+k^{B}\right)$. This together with the negative tariff revenue effect thus makes country $B$ worse off. Notice also that country $B$ 's welfare will always decrease if it does not import capital and adopts a tax-exempting policy towards capital. On the contrary, if $B$ is a capital importer, the capital returns effect benefits $B$ because it reduces the burden of repatriation. Therefore, the welfare of $B$ is more likely to rise when it is a capital importer than a capital exporter. An important lesson emerging from the analysis is that the perfect mobility of capital between member countries leads to a change in country $B$ 's welfare despite the fact that nonmember countries do not invest in country $B$. This spillover effects have been ignored in conventional analyses of capital mobility and economic integration. We have summarized the findings in the following proposition:

Proposition I: In a three-country, two-good specific factor model, assume

(l) two countries $A$ and $B$ form an economic region where the specific factor in the importable sector, capital, is perfectly mobile,

(2) the economic region faces exogenous world prices and imposes a common external tariff.

(3) country $j$ taxes capital income owned by member countries at the rate $\tau^{j}$ and country $A$ taxes nonmember capital income at $\tau$, and

(4) the nonmember country $C$ invests only in country $A$.

Then, with an increase in the foreign investment by $C$, it is more likely for the welfare of country $B$ to rise when it is a capital importer than a capital exporter. Moreover, the welfare of $B$ will decrease if it is a capital exporter and imposes a tax rate $\tau^{B}$ such that $\tau^{B} \leq \sigma^{B} i /\left(\sigma^{B} i+k^{B}\right)$.

Next, we turn to the welfare impact on country $A$. Similar to the case of country $B$, the welfare impact on country $A$ can be decomposed into the capital returns effect, the tax revenue effect as well as the tariff revenue effect, which are indicated in equation (5) by the terms (a), (b) and (c) respectively. As country $A$ has nonmember FDI in addition to the intra-regional capital ownership, both the capital returns effect and the tax revenue effect have two components, one for infra-regional ((al), (bl)) and the other for inter-regional FDI ((a2), (b2)). Defining $u^{A} \equiv\left(\partial k^{A} / \partial i^{*}\right)\left(i^{*} / k^{A}\right)$ and using $\sigma^{A}$ defined above, equation (5) can be rewritten as

$$
\begin{aligned}
& e_{u}^{A}\left(1-t c_{u}^{A}\right) \partial u^{A} / \partial i^{*}=-\left(i+i^{*}\right) r_{k k}^{A} \frac{\partial k^{A}}{\partial i^{*}}+\tau r_{k}^{A}\left(1-\sigma^{A} \mu^{A}\right) \\
& +\tau^{A} r_{k}^{A}\left[\partial i / \partial i^{*}-\left(i / i^{*}\right) \sigma^{A} \mu^{A}\right]-t r_{p k}^{A} \partial k^{A} / \partial i^{*}
\end{aligned}
$$

The first term on the right-hand side of $\left(5^{\prime}\right)$ represents the change in the payments to (returns from) the intramarginal units of "net" foreign capital, including FDI within the region as well as that from nonmember countries. Its sign depends exclusively upon whether country $A$ is a net capital importer or a net capital exporter. If $A$ is a net capital importer $\left(i+i^{*}>0\right)$, then its payments to the intramarginal units of foreign capital decrease with the increase in $i^{*}$, contributing positively to the welfare. The result will be reversed if $A$ is a net capital exporter. The second and the third terms are the marginal tax revenue from nonmember capital and regionally owned capital, respectively It is clear that the sign of the former depends on whether $\sigma^{A} \mu^{A}$ is less or greater than 1. (Note 4) When the elasticity of the marginal product curve of capital and/or the capital stocks elasticity with respect to nonmember FDI is so small (large) that their product is less (greater) than one, then the marginal payments to the capital owners of the nonmember countries will be positive (negative). The economic meaning is readily understandable. The greater the value of $\mu^{A}$ means the greater increase in capital used in country $A$ for a given increase in country $C$ 's FDI, On the other hand, a greater $\sigma^{\mathrm{A}}$ implies a greater decrease in the marginal productivity of capital for a given increase in capital stock $k^{A}$. Therefore, combining large $\sigma^{\mathrm{A}}$ and $\mu^{A}$ could depress the payments so much as to make the net marginal income of country $C$ negative, which in turn implies a decrease in tax revenue from nonmember capital income. The same logic is applicable to the marginal tax revenue on the capital owned by $A$ or $B$, mutatis mutandis. Here, however, whether $A$ exporting capital to $B$ plays a crucial role. Since $\partial i / \partial i^{*}=-\partial k^{A} / \partial i^{*}<0$, this term is negative as long as $A$ does not export 
capital to $B$. On the other hand, it could be either positive or negative if $A$ exports capital. Finally, the change in tariff revenue caused by the additional inflow of FDI from country $C$ of course contributes negatively to the welfare of $A$.

It is transparent that the welfare impact on country $A$ of the additional FDI from country $C$ is indeterminate. However, when capital income tax is unimportant (e.g. both $\tau$ and $\tau^{\mathrm{A}}$ are sufficiently small), country $A$ is more likely to be harmed by the capital inflows from nonmember country if it is a net capital exporter than a net capital importer. To the extent that country $A$ adopts a tax-exempting policy towards all kinds of capital, its welfare definitely declines if it is not a capital importer. Accordingly, we establish:

Proposition 2: Under the same assumptions as proposition 1, the impact of FDI from the nonmember countries on the welfare of country $A$ is generally indeterminate. However, when the revenue from capital income tax is unimportant, additional FDI from the nonmember countries is more likely to immiserize country $A$ if it is a net capital exporter than a net capital importer. To the extent that $A$ adopts a tax-exempting policy towards all kinds of capital, its welfare definitely declines if it is not a net capital importer.

A question frequently raised in the literature of economic integration is that whether there exists some kind of lump sum redistribution between member countries to ensure that none of the members loses (Wooton [1998]). However, the practical difficulty involved in a compensation scheme is usually formidable. Thus, it seems reasonable to seek an appropriate com-mon external tariff that can benefit both member countries from the increase in investment from country $C$. To simplify the discussion, let us consider the case where countries $A$ and $B$ levy zero tax on capital income, namely, $\tau=\tau^{A}=\tau^{B}=0$. This is in the spirit of the trade literature such as Brecher and Diaz Alejandro [1977] and Srinivasan [1983], and can release us from the complication of tax revenue effect. From equations (5) and (6), we obtain

Proposition 3: Under the same assumptions as proposition 1 , with $\tau=\tau^{A}=\tau^{B}=0$, the welfare of both member countries will rise if the common external tariff of the economic region satisfies

$$
t>\min \left[\left(\bar{k}^{A}-k^{A}\right) r_{k k}^{A} / r_{p k}^{A},\left(\bar{k}^{B}-k^{B}\right) r_{k k}^{B} / r_{p k}^{B}\right] .
$$

Recall that $\bar{k}^{A}-k^{A}=-\left(i+i^{*}\right)$ and $\bar{k}^{B}-k^{B}=i$. It is easy to arrive at the following corollary: when $\tau=\tau^{A}=\tau^{B}=0$, both member countries benefit from additional capital inflows from country $C$ only if country $A$ is a net importer of capital $\left(-i<i^{*}\right)$ and owns some capital in country $\mathrm{B}(i<0)$. Under the circumstances, both $\left(\bar{k}^{A}-k^{A}\right) r_{k k}^{A} / r_{p k}^{A}$ and $\left(\bar{k}^{B}-k^{B}\right) r_{k k}^{B} / r_{p k}^{B}$ are positive, and thus positive common external tariff ensuring welfare improvement in all the member countries does exist. (Note 5, Note 6)

Before closing this section, it is interesting to note that, by allowing perfect capital mobility in an economic region, the present paper generalizes some results obtained by Brecher and Diaz Alejandro [1977] and Srinivasan [1983]. In a standard two-good two-factor Heckscher-Ohlin model Brecher and Diaz Alejandro have demonstrated that the national welfare of a capital receiving country must go down with FDI if the tariff-protected importable sector is capital intensive and foreign capital receives the full (untaxed) value of its marginal product In the Heckscher-Ohlin framework as long as the capital receiving country remains incompletely specialized, the rewards to either factor will not be affected by additional foreign capital according to the factor-price equalization theorem. Using our notations, therefore Brecher- Diaz case is nothing but set $r_{k k}^{a}=\tau^{A}=\tau=0$, and $\partial k^{A} / \partial i^{*}=1$ in equation (5) (Note 7). Srinivasan has shown that the welfare effect of foreign investment is ambiguous if capital is the specific factor of the tariff-protected importable sector and foreign capital income is tax-exempting. This result is exactly the special case of equation (5') when $i=\tau^{A}=$ $\tau=0$. Furthermore, Srinivasan points out that the capital receiving country will benefit from additional FDI if it adopts free trade policy. Again, this is the special case of our model- it can be obtained by setting $i=t=\tau^{A}=$ $\tau=0$ in equation (5').

\section{Summary and Possible Extensions}

Given that the world has become increasingly segmented into trading blocks and the unprecedented upsurge of foreign investment activities it is by all means important and interesting to see how FDI among the regions affects the welfare of member countries in a particular economic region. While the conventional theories of international capital movements have extensively studied the welfare impact of investment from abroad, they have not investigated the issue in the context of an economic integration. The theoretical literature on international economic integration, on the other hand. has never dealt with the welfare impact on the member countries or an investment from nonmember countries. Attempting to bridge the gap in the literature, the paper 
investigates this issue in a "small" economic region characterized by a common external tariff and perfect capital mobility within the region. Using a specific factor model with capital as the specific factor of the tariff-protected importable sector, we have shown that the welfare of a member country will be affected by investment from nonmember countries even though the member country itself does not host the nonmember FDI.

Specifically, it is shown that: (1) for the member country which is not receiving nonmember capital, additional capital inflows into the economic region is more likely to be welfare-improving if it imports capital than export capital. Its welfare definitely decreases as long as it does not utilize capital owned by the other member country and impose no capital income tax; (2) for the member country which receives nonmember capital, additional capital inflows into the economic region will be immiserizing if it is not a net capital importer and imposes no capital income tax on all the capital income. Even with capital income tax, the welfare impact is more likely to be negative when it is a net capital exporter than a net capital importer, provided that the tax revenue effect is unimportant; (3) when capital income is tax- exempting in both member countries, a positive common external tariff ensures each of them to be benefited from nonmember investment exists only if both member countries are net importers of foreign capital.

Although the paper is based on a simple Ricardo-Viner model, it can still shed light on important policy issues. For instance, suppose there is a fixed sum of foreign capital to be introduced into an economic region. Worrying about the possible immiserizing effect of FDI, a member country therefore imposes a prohibitive tax to keep foreign capital out. However, when the other member plays host to the FDI, the first country may be made just as worse off after all. In other words, intraregional capital mobility may well make a country's policy toward FDI ineffective. In addition, the basic principle obtained in this paper is readily applicable in several other situations. In the first place, it is easy to show that both member countries will have a positive tariff revenue effect if capital is the specific factor of the exportable sector, a case mentioned but not analyzed in detail by Webb [1998] In this case, therefore, country $B$ 's welfare rises with more investment from non-member country as long as it does not own capital in country $A$. On the other hand, country $A$ 's welfare goes up if it is not a net exporter of capital and the tax revenue effect is sufficiently small. Secondly, to the extent that the economic region as a whole does not have monopoly power in international trade, the conclusions of this paper essentially stay the same even if there are more than two members in the economic region. Finally, the economic rationale concerning the tariff revenue effect, the tax revenue effect as well as the capital returns effect can be applied to explore the welfare impact of FDI from nonmember countries when there are more than two goods. Of course, depending on the patterns of trade, it is even more difficult to arrive at unambiguous conclusions about the direction of the welfare change in each member country.

\section{References}

Balasubramanyan, V. N. (1986). Incentives and Disincentives for Foreign Direct Investment in Less Developed Countries. In B. Balassa \& H. Giersch (Eds.), Economic Incentives. London: Macmillan. https://doi.org/10.1007/978-1-349-18204-6_15

Balasubramanyan, V. N., \& Greenaway, D. (1992). Economic Integration and Foreign Direct Investment: Japanese Direct Investment in the EC. Journal of Common Market Studies, 30, 175-193. https://doi.org/10.1111/j.1468-5965.1992.tb00426.x

Brecher, R. A., \& Diaz Alejandro, C. F. (1977). Tariff, Foreign Capital and Immiserizing Growth. Journal of International Economics, 7, 317-322. https://doi.org/10.1016/0022-1996(77)90048-4

Brecher, R. A., \& Findlay, R. (1983). Tariffs, Foreign Capital and National Welfare with Sector-Specific Factors. Journal of International Economics, 14, 277-288. https://doi.org/10.1016/0022-1996(83)90005-3

Giovannini, A. (1990). International Capital Mobility and Capital-Income Taxation. European Economic Review, 34, 480-488. https://doi.org/10.1016/0014-2921(90)90121-E

Heitger, B., \& Stehn, J. (1990). Japanese Direct Investments in the EC: Response to the Internal Market 1993 ?. Journal of Common Market Studies, 29, 1-15. https://doi.org/10.1111/j.1468-5965.1990.tb00378.x

MacDougall, G. D. A. (1960). The Benefits and Costs of Private Investment from Abroad: A Theoretical Approach. Economic Record, 26, 13-35. https://doi.org/10.1111/j.1475-4932.1960.tb00491.x 
Michael, M. S. (2002). From a Customs Union to a Common Market: The Need for Factor-Tax Harmonization. Economics Letters, 39, 79-84. https://doi.org/10.1016/0165-1765(92)90105-8

Miyagiwa, K. F., \& Young, L. (1996). International Capital Mobility and Commercial Policy in an Economic Region. Journal of International Economics, 20, 329-341. https://doi.org/10.1016/0022-1996(86)90025-5

Parai, A. P. L., \& Yu, E. S. H. (1989). Factor Mobility and Customs Unions Theory. Southern Economic Journal, 55, 842-852. https://doi.org/10.2307/1059466

Scully, G. W., \& Yu, E. S. H. (1974). International Investment, Trade Diversion and Trade Creation. Economic Record, 50, 600-604. https://doi.org/10.1111/j.1475-4932.1974.tb00209.x

Srinivasan, T. N. (1983). International Factor Movements, Commodity Trade and Commercial Policy in a Specific Factor Model. Journal of International Economics, 14, 289-312. https://doi.org/10.1016/0022-1996(83)90006-5

Tironi, E. (1982). Customs Union Theory in the Presence of Foreign Firms. Oxford Economic Papers, 34, 150-171. https://doi.org/10.1093/oxfordjournals.oep.a041541

United Nations. (1990). Regional Economic Integration and Transnational Corporations in the 1990s: Europe 1992, North America, and Developing Countries. UNCTC Current Studies, Series A, No. 15.

Webb, M. A. (1998). Preferential Trading Agreements and Capital Flows. Journal of Development Economics, 32, 181-190. https://doi.org/10.1016/0304-3878(90)90057-I

Wooton, I. (1998). Towards a Common Market Factor Mobility in a Customs Union. Canadian Journal of Economics, 21, 525-538. https://doi.org/10.2307/135436

Yu, E. (1985). Toward a Theory of Customs Unions with Foreign Investment. Economia Internationale, 38, 222-235.

\section{Notes}

Note 1. In the present context, an investment creation effect refers to the phenomenon that the integration effort triggers activities by transnational corporations which raise the aggregate level of FDI in the region, as measured by total stocks and/or flows: on the other hand, an investment diversion effect refers to a re-alignment of investment capital among members of the regional integration once protective barriers have been lowered or removed altogether (United Nations [1990]).

Note 2. See Balasubramanyam [1986] for a detailed discussion on the incentive and disincentive policies for FDI. In the case of EC, although it has reached agreements on trade policy and capital flows, so far there has been no consensus on the systems of taxation by individual member countries. In terms of capital income tax, it thus appears that member countries compete for nonmember investment by lowering tax rates, as witnessed from the tax exemption on foreign capital income by France (Giovannini[1990]).

Note 3. Let $m$ denote land, $l_{j}$ denote labor employed in sector $\mathrm{j}$, and the production functions be $q_{2}=\varphi 1\left(m, l_{1}\right)$ and $q_{2}=\varphi_{2}\left(m, l_{2}\right)$ respectively. As a result the revenue function can be written as $r(p, k)=q_{1}(p, m, k, l)+$ $p q_{2}(p, m, k, l)$ where $l=l_{1}+l_{2}$ denotes the total labor amount available for a country (for convenience we omit theparameters $\mathrm{m}$ and $l$ in function $\mathrm{r})$. It follows that $r_{p}-q_{2}+\left(q_{1 p}+p q_{2 P}\right)=Q 2 r_{p k}=\partial q_{2} / \partial k>0$.

Note 4. Since $\partial \mathrm{k}^{\mathrm{A}} / \partial \mathrm{i}^{*}>\mathrm{o}$, equation (4) gives us $\partial \mathrm{k}^{\mathrm{A}} / \partial \mathrm{i}^{\prime}<1$. Moreover, a country cannot invest more than its capital stock so chat $\mathrm{k}^{\mathrm{A}}+\mathrm{i}>\mathrm{o}$, implying $\mathrm{i}^{\prime} / \mathrm{k}^{\mathrm{A}}=\mathrm{i}^{*}\left(\mathrm{k}^{\mathrm{A}}-\mathrm{i}^{\prime}+\mathrm{i}\right)<1$ Therefore we have $\mathrm{u}^{\mathrm{A}}=\left(\partial \mathrm{k}^{\mathrm{A}} / \partial \mathrm{i}^{*}\right)\left(\mathrm{i}^{\prime} / \mathrm{k}^{\mathrm{A}}{ }^{\mathrm{A}}\right)<1$.

Note 5. As a consequence, adopting optimal, free trade policy by this "small union" would certainly ensure welfare improvement for both member countries provided that $0<-i<i^{*}$ and $\tau=\tau^{A}=\tau^{B}=0$

Note 6. Wooton [1998] demonstrates that the zero common external tariffs are optimal for a small customs union to move towards a common market. However, Michael [2002] shows that, even if the common external tariffs are set at zero, the perfect factor mobility within a customs union may not be welfare-improving if the inequality of tax rate on capital income exists across member countries. In our model, setting $t=0, \tau=\tau^{A}$ and using equations (5') and (6) gives us $\partial u^{B} / \partial i^{*}>0$ if $i r_{k k}^{B}>\tau^{B}\left(i r_{k k}^{B}-r_{k}^{B}\right)$ as well as $\partial u^{A} / \partial i^{*}>0$ if $\left[\left(\sigma^{A} u^{A} / i^{*}\right)(i+\right.$ 
$\left.\left.i^{*}\right)-\left(1+\partial i / \partial i^{*}\right)\right]$. Consequently, when both $\mathrm{A}$ and $\mathrm{B}$ are net capital importers, namely, $i<0$ and $i+i^{*}>0$, any $0 \leq \tau^{A}=\tau<1$ and $0 \leq \tau^{B}<1$ satisfying equation (3) would lead both countries to gain from the additional capital inflows from nonmember countries.

Note 7. Since FDI from $C$ into $A$ does not affect capital reward y, it will not cause any capital movement inside the economic region. All the capital increase therefore is confined in $A$, namely, $\partial k^{A} / \partial i^{*}=1$.

\section{Copyrights}

Copyright for this article is retained by the author(s), with first publication rights granted to the journal.

This is an open-access article distributed under the terms and conditions of the Creative Commons Attribution license (http://creativecommons.org/licenses/by/4.0/). 